This is a post-print version of the following article: Vargas-Urpi, Mireia (2014) Public service interpreting for Chinese immigrants in Catalonia: a study based on intepreters', coordinators' and users' view. Language and intercultural communication, 14 (4), 475-499. (Doi: 10.1080/14708477.2014.934691).

\title{
Public service interpreting for Chinese immigrants in Catalonia: a study based on intepreters', coordinators' and users' views ${ }^{1}$ \\ Mireia Vargas-Urpi* \\ Universitat Pompeu Fabra
}

\begin{abstract}
Public service interpreting (PSI) for the Chinese is a reality in many European states. However, research on the specificities of interpreting for this community is rather scarce. I therefore conducted a study to shed light on this topic, focusing on PSI for the Chinese in Catalonia, a region where this service began only relatively recently. This paper discusses the results of the research.

The research was conducted using a mixed method. Qualitative interviews were held with interpreters and mediators who work with Chinese people and with coordinators of PSI and intercultural mediation, while quantitative questionnaires were distributed among Chinese users of public services. The three sets of data were analysed independently, and triangulation was used to validate the results and to compare and contrast the information collected from each sample of informants. This article presents the triangulation and elucidates some specificities and challenges of PSI for the Chinese, namely, Chinese linguistic diversity, mediating between cultures and gaining users' trust. The discussion and conclusions stress the importance of including specific strategies to face these challenges in training and education, while also underlining the critical role of coordinators in the professionalisation of PSI.
\end{abstract}

1 This paper has been supported by MIRAS and InterAsia research groups. It is part of the RDI projects MEC: “El impacto de Asia Oriental en el contexto español: Producción cultural, política(s) y sociedad” (FFI201129090).

* Correspondence to: mireia.vu@gmail.com 
Keywords: public service interpreting, community interpreting, intercultural mediation, Chinese, intercultural communication, Catalonia

\section{Introduction}

In the first decade of the $21^{\text {st }}$ century, Catalonia's population profile changed very rapidly. In 2000 there were only 181,590 registered foreign citizens, but by the end of 2010 there were some $1,198,533$; an increase that amounts to $15.95 \%$ of the total population. The number of Chinese living in Catalonia also increased exponentially during the same ten-year period, from 4,461 registered Chinese in 2000 to 46,333 in 2010, and continues to increase. ${ }^{2}$

Public service interpreting (PSI) for the Chinese is a reality in many European countries. However, research on the specificities of interpreting for this community is rather scarce. The present article therefore seeks to shed light on this topic. Focusing on PSI and intercultural mediation (IM) for Chinese citizens living in Catalonia, it explores the challenges interpreters and mediators encounter when enabling communication between public service providers and Chinese users, and elucidates some of the specificities of mediating in intercultural encounters with the Chinese.

\section{A brief description of Chinese immigration in Catalonia}

Regional differences in China -traditionally between north and south, but more recently between urban and rural areas- are also visible among the Chinese who migrate to Catalonia. One of the most evident differences is in their mother tongues. 'Chinese' as a language actually refers to a 'family of languages', because it is divided into ten different mutually unintelligible languages or geolects (Rovira-Esteva, 2010, p. 195). In turn, each geolect is subdivided into dialects, of which there are an estimated 1,500 (Rovira-Esteva, 2010, p. 200). Even though dialects from the same geolect are assumed to be mutually intelligible, some actually are not.

Although most Chinese people living in Catalonia can speak Standard Chinese (also known as Mandarin), for most of them this is not their mother tongue but a second language acquired through compulsory education in China. In fact, Chinese immigrants' command of Standard Chinese varies according to the length of their education before emigrating from

\footnotetext{
${ }^{2}$ Data from Idescat, the Catalan Institute of Statistics. In 2012 there were 49,612 registered Chinese citizens in Catalonia. URL: http://www.idescat.cat/ (accessed $31^{\text {st }}$ May 2013).
} 
China.

According to Beltrán Antolín (2009, p. 137), up to $70 \%$ of the Chinese living in Catalonia come from the district of Qingtian and the prefecture of Wenzhou, both in Zhejiang province. Despite being close places, in Qingtian and Wenzhou mutually unintelligible dialects from the wu geolect are spoken. According to Rovira-Esteva (2010, p. 209), most immigrants from Qingtian and Wenzhou can speak Standard Chinese, but their accent is strong and the influence of their mother tongues is clearly evident in their spoken Mandarin.

Some Chinese have started learning Catalan or Spanish, the two official languages. However, adults are usually busy at work and this becomes a responsibility that is placed on their children, who will then assume a second responsibility: that of becoming natural interpreters or mediators for their parents. According to Beltrán Antolín and Sáiz López (2001, p. 33):

Children become translators for their parents in their relations with the host society, especially when dealing with government. When a son or daughter acts as translator for a family, he or she gives them a certain independence in this regard, in the sense that they do not need to rely on any other person from outside their group to solve their problems or to deal with their administrative procedures. ${ }^{3}$

Beltrán Antolín and Sáiz López raise two interesting issues. On the one hand, that children act as natural interpreters for their parents, a role that is not only accepted but also expected so the family does not have to rely on others. While children have easier access to learning local languages thanks to compulsory education, parents often find it more difficult due to time constraints. On the other hand, that children's help is preferred to that of 'outsiders', a preference that may be related to trust, as also mentioned in other articles (see, for instance, Edwards et al., 2005).

As for their use of public services, differences in the conception of services such as education, healtcare or welfare in China and in Catalonia sometimes become a source of misunderstanding between these two cultures. The different expectations on doctors' roles and healing practices have especially attracted researchers’ interest. Raga (2009), for instance, explains that health is conceived in terms of "cold" and "heat" (yin-yang), and when a disease appears it is believed to have been caused by a disturbance in the balance between cold and heat. Pregnancy is also believed to affect this balance, so women often change their diet while

\footnotetext{
${ }^{3}$ Original in Catalan; translation into English by the author.
} 
pregnant and after giving birth. Moreover, many women observe a period of postnatal confinement, during which even taking a shower is restricted. Holroyd et al. (2005), Ho Wong (2009) and Raga (2009) emphasise the importance of knowing these practices in order to offer adequate healthcare to Chinese women in labour. Empirical research has confirmed that some of these beliefs are held, as has a report by the Public Health Agency of Barcelona's Healthcare Consortium (Agència de Salut Pública, 2011), based on in-depth interviews.

This same report also points out that language is an important barrier to healthcare access, affecting "even Chinese citizens who have been living in Barcelona for many years" (Agència de Salut Pública, 2011, p. 38). According to the report, communication barriers “create much frustration and insecurity” for patients.

Several authors (Martin, 1998; Raga, 2009; Sánchez Pérez, 2009; Sproston et al., 2001, among others) agree that the Chinese use public services relatively little, especially healthcare and welfare. Previous studies often point to linguistic barriers as one of the main reasons for this trend, even though mistrust is also regarded as a major obstacle. Critical responsibility therefore seems to fall on interpreters and mediators to act as bridges between Chinese immigrants and local public services.

\section{Public service interpreting and intercultural mediation}

Whereas 'public service interpreting' (PSI), also known as community interpreting, has been clearly defined as the kind of interpreting that enables communication between local service providers and public service users who do not share the same language, the concept of ‘intercultural mediation’ (IM) has received different definitions, often influenced by the broader meaning of the term 'mediation'.

According to Katan (1999) and Pöchhacker (2008), translation and interpreting always include some kind of intercultural mediation. Pöchhacker (2008, p. 14) argues that "every interpreter is a mediator (between languages and cultures), but not every mediator is an interpreter”, partly because mediators often assume a broader role than interpreters.

In fact, reviews on the relationship between IM and PSI reveal two clear trends: some authors regard intercultural mediation as part of public service interpreters's role, while others argue that it is a separate profession.

Kaufert and Koolage (1984) and Bischoff et al. (2009), among others, discuss interpreters' role as 'culture brokers' or intercultural mediators when providing cultural information to help build a mutual understanding and overcome cultural barriers. Baraldi (2009) goes a step further and stresses the need for 'interpreter-mediated interactions'. This 
means that interpreters not only interpret but also help create a space for dialogue where migrant participants can express their views and concerns, especially considering the hierarchical differences and power imbalance between participants in this kind of interaction. Bancroft and Rubio-Fitzpatrick (2011, p. 185) describe three interpreter responsibilities: interpreting, mediation (e.g. clarification, checking for understanding, or cultural mediation) and mediation outside the session (e.g. client support and advocacy, such as making phone calls, accompaniment and reporting critical incidents).

Spanish authors who consider PSI and IM to be two different professions include Giménez Romero (1997, p. 142). He defines IM as an "intervention of third parties (...) between ethnoculturally different social or institutional actors”. IM aims to promote recognition of the Other's culture and enable the two parties participating to work more closely in the interaction, mutual understanding and communication, conflict resolution, and the adaptation of institutions. Giménez Romero’s definition describes a broader professional role that may even include conflict mediation. However, since intercultural mediators often mediate between cultures that do not share the same linguistic codes, interpreting may well be a function they assume. Prats San Román and Uribe Pinillos (2009, p. 8) and Qureshi (2009, p. 12) believe intercultural mediators need to adapt their role to the situations in which they work and include "linguistic interpreting" as one of those roles. In Italy, Rudvin and Tomassini (2008, p. 248) also attribute a broader role to intercultural mediators.

In Catalonia, the two professional profiles coexist. Interpreters usually work as freelancers hired on demand by associations and county councils (consells comarcals), and limit their tasks to liaison interpreting and the occasional short written translation. Intercultural mediators, however, tend to have full-time or part-time contracts -normally with town and city councils- and assume a wider range of functions: apart from interpreting for public services and translating notes and short leaflets, they also advise immigrant users on available services, participate in workshops about interculturality for public service providers, engage in activities promoting cultural diversity and social cohesion and, in some cases, even become conflict mediators (Arumí et al., 2011; Linguamón, 2010; Vargas-Urpi, 2012, 2013). Both the interpreters and the intercultural mediators enable communication between local service providers and users who speak languages other than Spanish and Catalan, which is why both are often the subject of research on PSI in Catalonia.

\section{Method}

The research presented in this article is part of a PhD thesis focusing on PSI and IM for the 
Chinese in Catalonia. The main objective of the research and the thesis is to describe and analyse the provision of mediated communication services to Chinese citizens living in Catalonia. In order to achieve this objective a mixed method was used: qualitative in-depth interviews were conducted with twenty interpreters or mediators for the Chinese and ten coordinators of PSI or IM services; and quantitative surveys were conducted among Chinese users of public services using questionnaires.

Qualitative interviews of interpreters and coordinators form the two main bodies of data. The interviews were conducted between March and December 2010 and they were informal and semi-structured; i.e., even though there was a list of questions and topics to be covered during the interviews, it was not a fixed guide, as it could be adapted to interviewees' answers. New questions could be added and the order of questions could be changed if, as interviewers, we felt it could help us obtain additional or relevant information.

Interviews were recorded and transcribed verbatim. Qualitative content analysis (Mayring, 2000) was used to assign codes and develop a formative analysis (Hertog et al., 2006). Some codes were related to our research questions or objectives and foreseen in the interview guides, but some codes were totally unexpected from the point of view of our research approach and, nevertheless, they were deemed important to describe the object of study. These transcriptions were then analysed using Atlas.ti, a program for qualitative data analysis.

Questionnaires for Chinese users of public services were distributed between October 2009 and March 2010 ${ }^{4}$ and between November 2011 and March 2012. They were written in Chinese and used closed questions (yes/no, multiple choice), as well as open questions where informants could expand their answers. ${ }^{5}$ Some of the questions included were based on the questionnaires used by Valero Garcés and Lazaro Gutiérrez (2008) and Arumí et al. (2011). Sixty-four questionnaires were collected. For answers to closed questions, percentages were calculated, while for open questions content analysis was used.

The three sets of data were then triangulated. Triangulation is often used in social sciences to validate the information obtained from different informants or by means of different data-collection methods. Moreover, by contrasting and comparing different views on the same situation, triangulation also enabled a more holistic approach to the object of study.

\footnotetext{
${ }^{4}$ The first period of collection of questionnaires was part of a study developed by the MIRAS research group and funded by the Catalan Agency for Research (ARAFI 2010) (Vargas-Urpi et al, 2013).

5 The original questionnaire can be consulted in Appendix 1.
} 
This paper presents the triangulation of the information concerning the challenges and specificities of mediated communication for the Chinese in Catalonia, which is only part of the results published in the aforementioned thesis. This information is mainly found in interpreters' and mediators' interviews, even though coordinators' feedback as well as users' views are also valuable to complement and contrast interpreters' and mediators' responses.

\section{Samples of informants}

As stated before, the data were collected from three different samples of informants. A detailed description of each sample may be useful to contextualise the information they provided.

\subsection{Public service interpreters and intercultural mediators}

All the interviewees were interpreters or intercultural mediators working in Catalan public services at the time of the interview. Fifteen were women and five were men. This gender distribution is frequent in PSI, which has been described as a female-dominated profession (Arumí et al., 2011).

Twelve interviewees were Chinese, seven were European and one was Latin American. Seven of the twelve Chinese interviewees migrated to Catalonia with their parents when they were still children or teens, ${ }^{6}$ while the other five went to Catalonia to further their studies. ${ }^{7}$ All the informants had lived in the other country at some point (China or Catalonia), though some longer than others (one year to more than fifteen years). This information already gives us some clues about interviewees’ linguistic competence: while interpreters from Zhejiang and Fujian may share their mother tongue (Qingtian, Wenzhou or Fujianese languages) with Chinese users of the same origin, the others must rely on Standard Chinese as a lingua franca to communicate with Chinese users.

In the case of Chinese interpreters who had migrated to Catalonia with their parents, some of them had already started interpreting as children, assuming this new responsibility that Chinese migrant parents often place on their children (Beltrán Antolín and Sáiz López, 2001). However, informants' professional experience as public service interpreters or intercultural mediators was diverse: five of them had been working in the field for less than a year, while four of them had been interpreters or mediators for five to ten years. Seven

\footnotetext{
${ }^{6}$ They came from Zhejiang (4), Fujian (2) and Shanghai (1).

7 They came from Jiangsu (2), Beijing (1), Shandong (1) and Taiwan (1).
} 
worked full-time, five part-time and eight occasionally on demand, as freelancers.

The sample of interviewees was extremely heterogeneous, reflecting the inherent diversity in the professional practice of PSI and IM in Catalonia. This heterogeneity also needs to be taken into acount when examining the various answers received from informants.

\subsection{Coordinators of PSI and IM services}

In this sample, informants can be grouped in the following categories:

- Six of them were coordinators of interpreting services in a city council, an association or a trade union. They were in charge of registers of interpreters, some of which were considerably large (INF23's register had more than 120 interpreters), ${ }^{8}$ while others (those overseen by INF24 and INF25) were very small (no more than ten interpreters).

- Two of them were consultants for citizenship projects in local councils near Barcelona. They were responsible for creating, implementing and supervising programmes that would enhance intercultural cohesion in their respective cities.

- Two of them were in charge of projects that included training in IM as well as guiding and coaching during the trainees' internship period. They were also in charge of implementing IM services for the organisation where trainees would take their internship.

As in the previous case, this sample is heterogeneous and, again, it reflects the inherent diversity in the provision of intercultural communication services in Catalonia.

\subsection{Chinese users of public services}

In the sample of Chinese users, $52 \%$ said they were men, $42 \%$ women and $6 \%$ did not give their gender. Although they were asked for their specific place of birth in China, $20 \%$ of the sample simply answered "China", and $12.5 \%$ did not answer the question. Specific data is therefore only available for two thirds of the sample. Of those surveyed, $28.1 \%$ said they were from Zhejiang province and 18.8\% from Fujian. The remaining informants are from various provinces, as reflected in Figure 1.

\footnotetext{
${ }^{8}$ The abbreviation "INF" followed by a number will be used to refer to interviewees. Informants 1-20 are interpreters and mediators, while 21-30 are coordinators of PSI or IM services. For users, the letter "U” followed by a number will be used.
} 


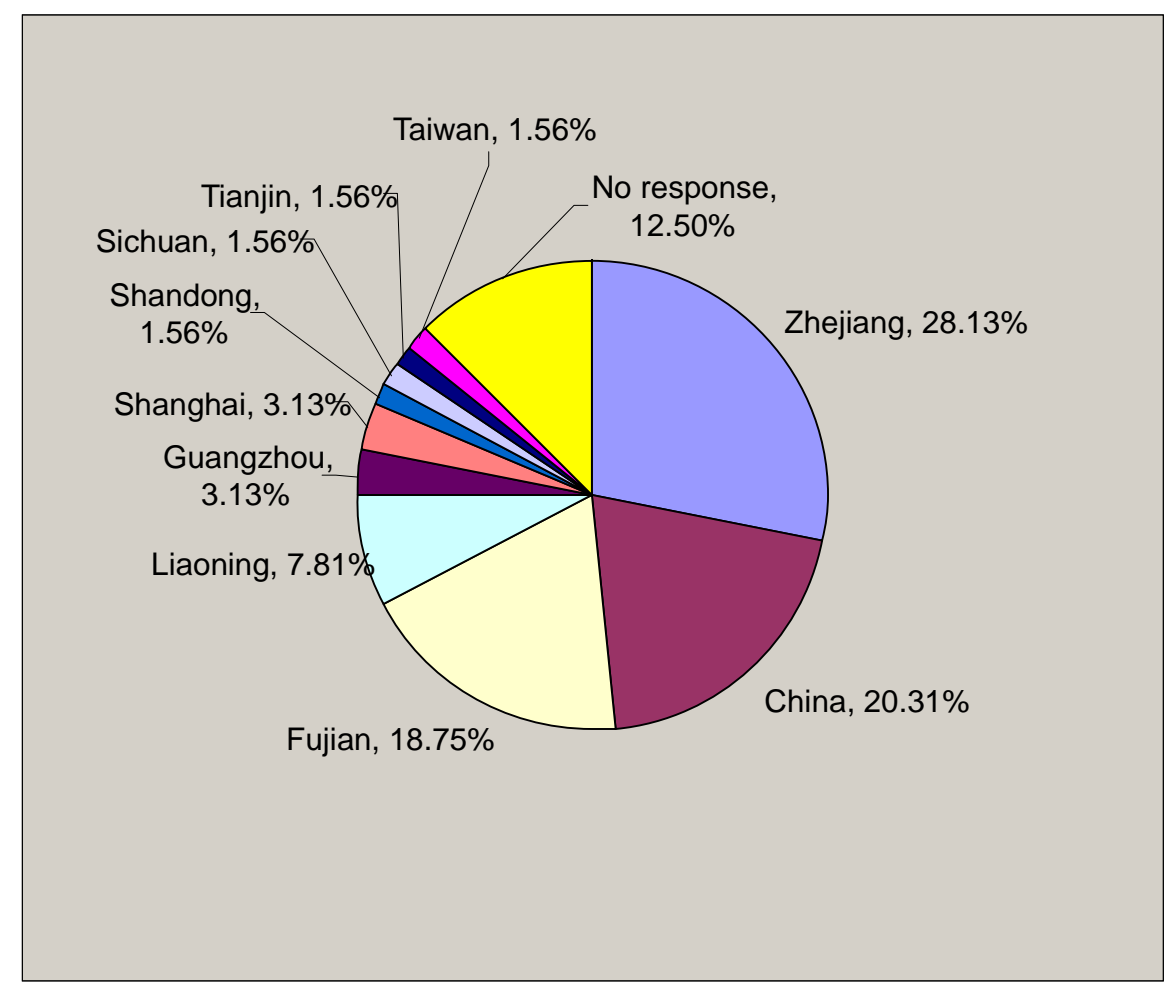

Figure 1. Origins in the sample of Chinese users.

When asked what language they usually speak, they replied as follows: ${ }^{9}$

Table 1. Users’ declared native language.

\begin{tabular}{|l|c|}
\hline Language & No. of respondants \\
\hline Chinese (no geolect/dialect given) & 29 \\
\hline Standard Chinese or Mandarin & 11 \\
\hline Qingtian dialect & 4 \\
\hline Fujian dialect & 2 \\
\hline Dialect of Zheijiang & 1 \\
\hline Dialect of Changle (Fujian) & 1 \\
\hline Cantonese & 16 \\
\hline No response & 1 \\
\hline
\end{tabular}

The lack of specific answers to this question makes it difficult to have an exact idea of the actual languages spoken by the informants in this third sample. However, based on the information concerning informants’ origins, we can deduce that dialects deriving from wu -

\footnotetext{
${ }^{9}$ One respondant declared two native languages: Chinese and the dialect of Changle (Fujian).
} 
such as Qingtian and Wenzhou- are probably the most common dialects spoken.

\section{Challenges in PSI and IM for the Chinese in Catalonia}

This section is based on the triangulation of the information collected from the three samples described above. It must be noted that different questions were asked to each of the samples, which is one of the reasons why each corpus of data has been analysed separately. Considering the scope of the present article, three different challenges will be described in this section: linguistic diversity, cultural references and trust and confidentiality.

\subsection{Linguistic diversity}

Linguistic diversity in Catalonia must be regarded from a double perspective: on the one hand, both Catalan and Spanish are considered official languages ${ }^{10}$ and both are used in public services; on the other hand, we have already mentioned the wide range of geolects and dialects that the term 'Chinese' may include.

Concerning Catalonia's official languages, all the interpreters and mediators interviewed had a good command of Spanish. Among Chinese interpreters who had migrated to Catalonia as teenagers, most could speak Catalan fluently and only two said they felt more confident speaking in Spanish, even though they could understand Catalan perfectly and were trying to improve their spoken Catalan.

Chinese interpreters who went to Catalonia to continue their studies already had a good level of Spanish when they arrived, so most speak Spanish much more fluently than Catalan. Non-Chinese interpreters born outside Catalonia are in a similar situation: despite understanding Catalan, they tend to use Spanish to communicate, although some of them say they are trying to increase their use of Catalan. Finally, interpreters born in Catalonia are bilingual in both official languages, Catalan and Spanish.

From the coordinators' point of view, the command of local languages is a deciding factor when employing interpreters and mediators. Indeed, for the register coordinated by INF27, a good command of Catalan is the only requirement for being admitted, even if interpreters can communicate in Spanish. Training, experience and personality are considered secondary factors. When potential candidates cannot speak Catalan, INF27 encourages them to learn it and to apply again once they have done some basic courses. INF23, INF25 and

\footnotetext{
${ }^{10}$ There is a third official language, Aranese, which is a dialect of Occitan and is spoken in the Val d'Aran county, in north-west Catalonia.
} 
INF26 also value knowledge of Catalan and encourage interpreters to learn it, but they accept interpreters without Catalan if they have a good level of Spanish.

Thirteen of the interprerters and mediators interviewed say that the use of Chinese varieties by users is the main difficulty they encounter in PSI. Of those thirteen, five are nonChinese and eight are Chinese. It must be noted that, despite users' efforts to speak Mandarin, they may still be difficult to understand because of their mother tongues' influence, although INF3 says she got used to this Standard Chinese tinged with the accent of certain dialects.

Using Standard Chinese as a lingua franca is a common strategy in interpretermediated interactions if interpreters and users do not have the same mother tongue. However, nine informants recall meeting users who did not speak Standard Chinese. According to their experience, these situations are rare and the solutions applied are diverse. Five informants present examples of relay interpreting, where a third person (a user's relative or friend) interpreted from the user's variety into Standard Chinese and vice versa. Other informants mention different solutions. In some situations, a very rudimentary Standard Chinese is used, while in others, different linguistic varieties are combined, despite being mutually unintelligible. INF7 remembers a situation where a mix of Qingtian and Wenzhou dialects was used:

\section{Extract 1}

[INF7, female Chinese intercultural mediator]

She [the user] was mixing the Qingtian and Wenzhou dialects and I had to decipher what she was saying to me and then translate it. That interview was a bit complicated. (...) At first I tried to speak Standard Chinese, but I saw the mother was not understanding me, so I started using the Wenzhou dialect. Then I noticed the mother could understand me, if I kept speaking the Wenzhou dialect. But when she tried to use it, while she was talking, it was a bit difficult for her and she just mixed the two dialects.

Even though interpreters try to overcome this linguistic barrier as best they can, communication in this kind of situation is poor and nearly comparable to communication between providers and users who have a very elementary knowledge of Catalan or Spanish. This kind of situation is challenging for the interpreter, but also dangerous: communication may be partial, with only the information that is understood being transmitted, or even biased, if interpreters decide to rely on their intuition to fill in the gaps that they have not fully understood. 
Nevertheless, six informants say that Chinese linguistic diversity is not a difficulty they commonly face because -they say- most users can speak Standard Chinese. Three informants deny having encountered users who could not speak Mandarin, which contrasts with the examples presented before.

In the second sample of informants, coordinators are not very sensitive to Chinese linguistic diversity. Even though some of them (INF22, INF23, INF27) express a preference for Chinese interpreters, none of them says that this is because the Chinese interpreters have a better command of a second variety of Chinese, in addition to Standard Chinese.

Finally, only $17 \%$ of Chinese users said they had once been assigned an interpreter with whom they did not share the same linguistic variety. This low percentage suggests that this is not a common problem among users. Seven of these respondents also answered the open question related to this issue and provided more information about their personal experience. Three of them explain that they looked for another interpreter with whom they shared a common language; two of them say they continued with the meeting despite the communication barriers, relying on signs and gestures (U13) or using a dictionary (U17); informant U64 explains that he could not finish the procedure he was trying to complete; and informant U28 explains that the problem was that they relied on a friend's son whose competence in Chinese was limited. Again, though, despite the great linguistic diversity of the Chinese, problems are rarely encountered.

\subsection{Interpreting cultural references and mediating between cultures}

According to the interpreters and mediators interviewed, it is difficult not to mediate in certain circumstances. Interpreters actually feel frustrated when they are not allowed to mediate. INF16 admits that "sometimes, working just as an interpreter, I feel helpless, useless, because in certain cases I need to explain how the Chinese culture is”. This point of view is shared by most of the interpreters and mediators in the sample, who value positively the possibility of expanding their role when cultural references arise in a conversation.

When discussing this need for mediation, various interpreters and mediators talk about cultural references related to cultural practices. Some informants mention the differences in the conception of education (INF6, INF7, INF9, INF12, INF15). For instance, according to INF7, teachers in China have a closer relationship with pupils' parents than teachers in Catalonia. Chinese parents in Catalonia therefore accuse teachers of "not caring enough" for their children. Moreover, according to INF7, parents do not understand the teaching practices used in Catalan schools and often ask why their children "only play” when they are at school. 
All these differences in the approach to education have also been reported by Beltrán Antolín and Sáiz López (2001) in their studies about the Chinese in Catalonia. Furthermore, these differences may require some kind of explanation or mediation if the subject arises in a school interview, especially considering that the interpreter may be the only participant who is aware of their cultural implications.

When talking about cultural differences in healthcare settings, INF9 recalls a particular occasion when a patient gave some extra money to the doctor, which is perfectly normal in mainland China (Hamed, 2009, p. 55). ${ }^{11}$ The doctor rejected the gift, which made the patient feel very embarrassed. The informant regrets not having better explained the meaning of the gesture to provoke a more sympathetic response from the doctor.

INF4 describes a situation where taking into account a specific cultural practice helped her win the user's trust:

\section{Extract 2}

[INF4, female Chinese mediator]

Even though I was there, she [the user] did not trust me at all. I had been working with her, telling her I'm a professional, but I just couldn't gain her trust. Then, one day, I remember she was heavily pregnant and the provider wanted to schedule a meeting just after the birth, and the only thing I said was: "Don't ask her to meet during the confinement after birth, because in China women fully respect this practice”. And then I translated this into Chinese. That made our relationship change: from that moment on, the Chinese user started trusting me! (...) Now, she trusts me completely.

Even though the outcome in this situation was very positive from the three participants' point of view, the interpreter was generalising somewhat. She made it sound like all Chinese women, without exception, respect the confinement period after birth. Even though many of them do respect it (see, for instance, Holroyd et al., 2005; Ho Wong, 2009; or Raga, 2009), this is a dangerous generalisation that could just portray a simplistic view of the Other.

Cultural references can also appear embedded in communication patterns. Again, some kind of mediation inside the session may be useful in order to prevent misunderstanding

\footnotetext{
${ }^{11}$ Patients give the hongbao (红包) or red envelope with extra money to doctors in the hope of receiving better treatment. Some Chinese hospitals now strictly prohibit this practice.
} 
in situations like the one presented in the next excerpt:

\section{Extract 3}

[INF5, female Catalan mediator]

Maybe he [the user] is saying: "Yes, the other day, I know my child didn’t go to school, so I beat him up for not going!” So you have to transmit that he is saying he beat him, because that is what he really thinks to be the only thing he can do, you know? Sometimes, transmitting this kind of information is difficult. And then, of course, you always have to add something: "No, he says he beat his son, but he only says that because he thinks that's the only thing he could do". He says that because he thinks that's the right thing to do, when in fact... you know.

According to INF5, it is important to transmit not only the explicit information, but also the implicit content of the messages, whether it is a rhetorical device (irony, sarcasm, metaphors), a feeling or an emotion. In the example presented, if the explicit message were the only one transmitted, the social worker would assume there is child abuse. Putting the father's words in context is therefore essential to prevent misleading conclusions.

Moreover, in the previous excerpt, the Chinese user tells a lie because he thinks that it is what is expected of him. This could be considered an example of how the concept of 'face' influences communication: the user, to avoid losing face, says what he thinks the provider might be expecting to hear.

In the Western tradition, most definitions of 'face' refer to Goffman's (1967, p.5) use of the term. However, in the Chinese tradition, Hu already defined the term in 1944 by describing how the Chinese regard mianzi and lian. Hu defined mianzi as "a reputation achieved through getting on in life, through success and ostentation" and lian as "the confidence of society in the integrity of the ego's moral character, the loss of which makes it impossible for him to function properly within the community” ( $\mathrm{Hu}, 1944$, p. 45). Both concepts are often translated in English as "face”, which is their main meaning, even though the above definitions suggest there are slight differences between the two terms. We can therefore assume that 'face' is a broader concept in Chinese culture. 'Losing face' and 'giving face' are common expressions in Chinese and face-related strategies are used, for instance, to ask for favours (Hwang, 1987; Dong, 2008), refuse things (Gao, 1998; Yang, 2008), receive praise (Yu, 2003; Qu and Wang, 2005) or avoid conflict (Gao and Ting-Toomey, 1998).

Concerning 'face', INF6 talks about polite answers to avoid giving a straight "no" 
(i.e., refusal strategies), which may even become a "yes” just to protect one's face and that of the interlocutor. INF7 explains that the Chinese tend to avoid direct criticism when talking. When both interlocutors are Chinese, the same communication rules apply to both and implicit criticisms are easily understood. On the other hand, when interlocutors do not share the same cultural horizons (Gadamer, 1975, 1977), ${ }^{12}$ an explanation may be necessary to avoid a misunderstanding, as seen in the previous example.

Other examples of intercultural references that may need some kind of mediation are found in non-verbal communication. Most interpreters and mediators interviewed admit that certain differences in non-verbal behaviour must be explained in order to prevent misconceptions of the Other. One such example is smiling or laughter: Chinese people might smile or laugh in an awkward situation just to ease the situation, restore harmony (Bi, 1998; Sales Salvador, 2003; Sun, 2010) and, by extension, protect participants' face. The Catalan interlocutor is often quite shocked by this kind of smile, not expecting it in such circumstances. INF17 and INF18 recall occasions when local public service providers got angry with Chinese users because the users were laughing while the providers were telling them off for something. The Chinese people laughed because they felt embarrassed, but in the public service providers' eyes the Chinese were mocking them. In both situations, interpreters had to add an explanation to help resolve the misunderstanding.

Concerning the information from the second sample, most coordinators are fully aware of the difference between interpreting and mediation as professional practices (VargasUrpi, 2012). Most coordinators of PSI services insist on the importance of being "invisible" while interpreting (Angelelli, 2001), although some of them also recognise the interpreters' function as "cultural decoders" (INF27, INF25). INF22 is unwavering in this respect and says she has to remind interpreters: "No, you are not mediating here, you cannot intervene; be careful with your words. Here, you must be literal: what I'm told is what I tell you.” This advice can be misleading, because it does not take into account the cultural differences already discussed in this paper, which may need mediation during the session to prevent misunderstanding or misconception.

Finally, $11 \%$ of users surveyed acknowledge that they often receive explanations about Catalan culture and traditions from interpreters. 52\% say it happens sometimes, 19\%

\footnotetext{
${ }^{12}$ Gadamer $(1975,1977)$ introduces the concept of a cultural horizon "that is common to everyone who forms part of a given sociocultural group in a given place in a given era. Members of such a group will share the same cultural references within (but not beyond) their horizon.” (Golden, 2009, p. 388).
} 
say they have never received that kind of information from interpreters and $19 \%$ did not answer the question. These figures seem to indicate that interpreters do not always mediate, but do sometimes.

\subsection{Reaching users: trust and confidentiality}

Trust and confidentiality are regarded as two key elements to ensure an effective interpretermediated interaction. Edwards et al. (2005) stress that users need to trust interpreters and that users value positively interpreters who show empathy and closeness to them. For this reason many of the users interviewed in the study by Edwards et al. preferred relatives or friends as interpreters, rather than professional interpreters.

Rudvin (2007), meanwhile, tries to ascertain whether interpreters from collectivist cultures show a more partial attitude towards users of the same origin. More specifically, Rudvin (2007, p. 64) quotes Ytreland (2004, p. 48) to show the example of a Chinese business interpreter who tends to show a certain feeling of affiliation to her own group, a common feature in collectivist cultures: "Interpreter D is a Chinese national, and she often finds herself in a dilemma, as the Chinese tend to see interpreters as an aid to assist their countrymen in reaching their goal in the negotiation”.

In this sense, one may think that it may be easier for users to trust interpreters who are of the same origin. INF11, a Chinese mediator, feels she is much more relied on because of this national affiliation, as may be noted in the following extract:

\section{Extract 4}

[INF11, female, Chinese mediator]

Of course, you are there to help them and, in addition, you are one of them! They see a Chinese person, someone trustworthy, and they tell me a lot of things. They even tell me things they don't tell the doctors. So, when I'm with them I warn them: "If there's anything you don't want the doctor to know, don't tell me, because I'll have to tell the doctor, because that's my job, you know?”

However, group affiliation can also lead to ethical dilemmas. INF7 was in a difficult situation when some Chinese parents asked her to take their side because of their shared nationality. They even became angry when she tried to remain impartial. Group affiliation can therefore sometime be a double-edged sword in terms of trust: in certain situations it can make interpreters immediately gain users' confidence, but in others it can become a real 
obstacle to impartiality while interpreting.

Nevertheless, even though group affiliation seems to enhance users' expectations of interpreters, that does not necessarily mean trusting them more. In fact, two interpreters explain that because they are not Chinese, users feel more comfortable with them. INF9, a Spanish interpreter, acknowledges that "sometimes they tell me they hire me because they prefer hiring a Spanish translator, to keep it more secret”. Trust is very much related to confidentiality, particularly in a culture where one's face or dignity basically depends on the image portrayed to others, as we have seen in the descriptions of mianzi and lian.

INF17, who is Taiwanese, presents another example where this relationship between trust, confidentiality and face stands out:

\section{Extract 5}

[INF17, female, Taiwanese mediator]

Well, you know, for the Chinese [attending social services] is very embarrassing, it's diu lian [face-losing], and there are many things they don't want to sort out with anyone else. One of my users tells me I make him feel very confident because I'm from Taiwan. Because, for instance, they [users] have also found mediators in the hospital, and they have stopped going there because of the mediator, the translator, because she just blabs with other mediators or acquaintances. And then they stopped going, they gave up their treatment because of that, because they prioritise their dignity over their health.

In this specific example, the lack of trust towards the mediator had a very negative outcome: users immediately stopped attending the service where the mediator worked. Even though the importance of confidentiality and trust may be extrapolated to users from other cultures, it must be noted that face (mianzi or lian) plays a key role in interpersonal relationships in Chinese culture and has traditionally had a deep influence on people's behaviour (Hu, 1944; Hwang, 1987), as we have already noted before. INF4 (36:87) and INF6 (38:75) also agree that the Chinese living in Catalonia do not usually ask for help at welfare and social service offices for fear of losing face, a tendency Martin (1998) also described in a study developed in Australia. Since merely attending welfare offices is regarded as a way of losing face, being able to trust interpreters' confidentiality becomes even more important in such circumstances.

Concerning the information provided by the second sample of informants, opinions towards confidentiality and codes of professional conduct are diverse. All the informants 
stress the importance of confidentiality, and three of them (INF22, INF23, INF27) say they have written a code of professional conduct that all their interpreters have to sign. It must be noted that these three informants are in charge of the largest registers of interpreters included in the second sample. Two informants (INF25, INF30) explain that although they have not developed any kind of code of conduct, confidentiality is revised and discussed in follow-up meetings or in-house training sessions, where coordinators always remind the interpreters of the importance of keeping information confidential to avoid losing users' trust. Two informants (INF26, INF29) say they do not need written codes because they fully trust the interpreters who work for their city councils. However, INF29 says she would be open to developing one if it could help increase users' trust in the services provided.

Finally, regarding users' preferences for interpreters, in a sample of 64 users, 19 of them indicate that they prefer non-Chinese friends who can also speak Chinese, 13 say they prefer Chinese friends who can also speak Catalan or Spanish, 9 say they prefer governmenthired professional interpreters and 9 say they prefer relatives (figure 2). ${ }^{13}$

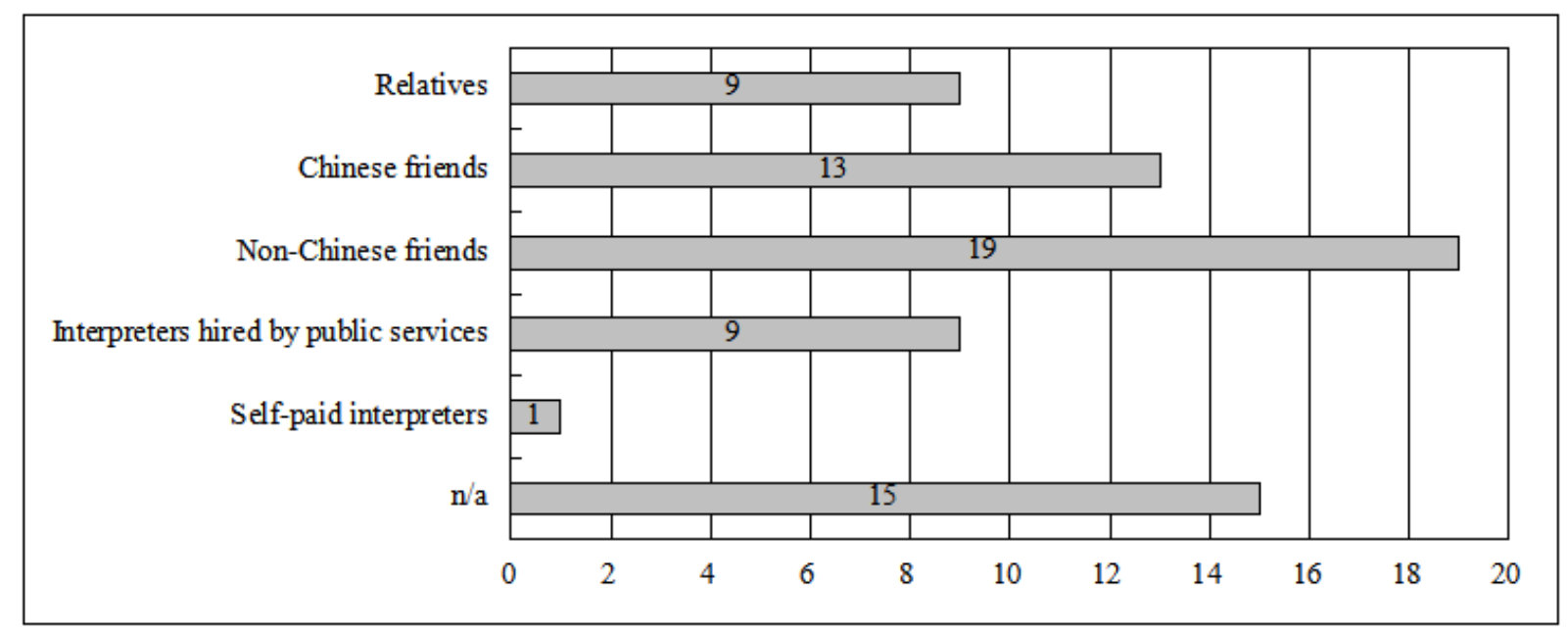

Figure 2. Preference for interpreters

As these responses come from a small-scale sample, it may be difficult to weigh the actual preference towards one profile or another. Answers were diverse, but trust towards nonChinese friends becomes evident in this sample.

To have a broader image of users' preferences, they were also asked what they value most in interpreters, with eighteen users providing information. Six users refer to patience or active listening skills. Five mention honesty and three responsibility, which are qualities closely related to the sense of trustworthiness that interpreters convey. Four users mention

\footnotetext{
${ }^{13}$ Users could choose more than one option in this question and some of them chose two answers.
} 
kindness, three morals and two closeness. Only one user refers to linguistic skills and knowledge. All in all, users value interpreters' personality and attitude more than their specific interpreting skills. This is perhaps because it is difficult for them to assess interpreters' performance in the local languages.

Finally, when asked if they receive advice from interpreters on how to answer the questions from providers, 20 users say that they often do and 16 that they do sometimes, which seems to indicate that more than half the sample have received advice from interpreters. Half the sample also say they often ask interpreters for advice, while 13 of them say they only ask for advice sometimes. Only 9 respondants deny asking for any kind of advice from interpreters. These figures reinforce the idea that users tend to seek some kind of help from interpreters, regardless of their origin.

\section{Discussion}

The present study reveals certain trends and features of PSI for the Chinese in Catalonia. However, certain limitations in the present research should be mentioned before its findings are discussed. The first limitation is that a small sample was used to collect the data. Furthermore, many of the respondents did not answer some of the questions, perhaps because of their lack of literacy in written Chinese or because they were concerned about the confidentiality and purpose of the survey, even though this was clearly explained both orally and in the introduction to the printed questionnaire. Only two largely incomplete questionnaires were excluded, with those that lacked only a few answers included in the analysis. Although the data are valuable for a study of PSI and MI for the Chinese, given the small sample, the findings cannot be assumed to reflect all Chinese users of public services in Catalonia or further afield.

Another limitation is that information was not collected from public service providers. Such information could have allowed a more comprehensive description of the object of study. However, the analysis presented may still be regarded as balanced, since opinions from both the host culture (coordinators) and the immigrant culture (users) have been included, as well as those of the third culture (interpreters and mediators). ${ }^{14}$

In the present article, three different kinds of challenges have been discussed: 1) linguistic, 2) cultural and 3) role-related. The linguistic challenges are perhaps the challenges

\footnotetext{
14 Bahadir (2004, p. 816) quotes Bhaba (1996, p. 54) to introduce the idea of the interpreter’s third culture, an intermediate culture based on the two cultures that the interpreter works between.
} 
most specifically related to interpreting for the Chinese, since the cultural and role-related challenges may also be extrapolated to interpreting for people from other distant cultures.

We often think of PSI as giving users the opportunity to express themselves in their mother tongue when using public services. Some authors even advocate that interpreters' linguistic competence should cover all varieties of their working languages (Abril and Martin, 2008, p. 113). However, this is sometimes not the case when interpreting for the Chinese, where a second acquired language (Standard Chinese) is often used as a lingua franca to enable communication with users' whose mother tongues are local dialects. According to the answers from the sample of interpreters and mediators, and from the sample of users, situations in which communication has not been possible because the interpreter did not know the user's linguistic variety (e.g. the Qingtian, Wenzhou or Fujian dialect) are scarce, as most Chinese immigrants can speak Standard Chinese, but they do occasionally arise.

Promoting Chinese language varieties in PSI training would not be easy. First, it must be noted that Chinese linguistic varieties are not recognised in formal education in China and can only be learnt at home. Second, promoting Chinese varieties would favour only Chinese interpreters or interpreters from specific regions in China. To avoid this bias towards a specific linguistic variety, training should be diversified to cover as many varieties as possible, but doing so would be impractical and economically unviable.

Although training in Chinese varieties is not promoted, the varieties should still be recognised if an interpreter can demonstrate a good command of any of them. Service coordinators should especially take into account the knowledge of a second variety in addition to Standard Chinese as added value for certain interpreters. Coordinators can only take such knowledge into account if they are aware of Chinese linguistic diversity and of the most commonly spoken varieties in their line of work, but the interviews with coordinators show that this is not always the case.

The second kind of challenge analysed is cultural references that may need some kind of mediation to prevent the public-service worker from misunderstanding the interlocutor or even the Chinese Other in a broader sense. Some of these references are more evident than others, such as when they are related to a specific and widespread cultural practice, but some of them are just embedded in communication patterns and may be more difficult to manage. These are often related to cultural values and sometimes have a clear influence in interpersonal relations. Training should take into account both kinds of cultural challenges to improve interpreters' cultural and intercultural competence. Interpreters who are sensitive to the influence of interlocutors' own culture in communication and interpersonal relations are 
more likely to try to mediate between the two speakers.

Of course, Chinese culture should not be regarded as monolithic. Most Chinese immigrants in Catalonia and in the third sample come from rural areas (Qingtian and Wenzhou, in Zhejiang province), where many traditional practices that are disappearing in urban China are still widespread. For instance, one of the Chinese interpreters in the first sample comes from Nanjing and says she is unaware of some of the cultural beliefs or traditions followed by many Chinese immigrants in Catalonia (INF1). Even though respondents seldom mentioned regional cultural differences, they do exist, in addition to linguistic differences.

Cultural and intercultural competence is closely related to IM strategies. The information from the first sample shows that, even though interpreters and mediators are aware of the importance of mediating when certain cultural references are encountered, many of them tend to adopt the role of culture brokers and even fall into generalisations when trying to explain cultural references. PSI training could give interpreters the tools to mediate in this kind of situation without generalising or talking on behalf of any of the participants. Bancroft and Rubio-Fitzpatrick (2011, p. 167) suggest a model for mediation where transparency is ensured and side conversations are avoided. According to the authors, mediation should only be used when "a significant barrier to communication or service delivery justifies the time and risk involved in mediating”. With this warning, Bancroft and Rubio-Fitzpatrick try to prevent interpreters from losing their main function: interpreting. In this model, interpreters must always identify themselves before starting the mediation and must not provide opinions, advice or erroneous information. Instead, interpreters must allow the primary participants to speak to help them find common ground for understanding.

It is important for PSI training to provide this kind of technique to interpreters to avoid mediation practices that would harm the provider-user relationship. PSI training should also offer a space for discussing the advantages and risks of mediation during an interpreted session. Furthermore, this discussion should be made available to PSI service coordinators. Coordinators can have a strong influence on interpreters' behaviour, including providing specific advice on how to mediate, and when monitoring interpreters they could have a very positive effect on interpreters' daily practice and performance.

Finally, concerning role-related challenges, the answers provided by informants show that trust is a key element to effective communication in an interpreter-mediated interaction, as had already been discussed by Edwards et al. (2005). Users' answers are especially valuable in this part of the analysis. Users need to trust interpreters before they will share 
private and sometimes compromising information. In these situations, interpreters' attitude is much more important than their origin, as it is the only way for them to gain users' trust. This is also important from the perspective of PSI training: trainers should make future interpreters aware of the importance of their attitude and provide them with specific tools to improve it.

One of these tools could be how to introduce themselves. Most interpreters and mediators in the first sample start their sessions with hardly any introduction (Vargas-Urpi, 2013). However, a full introduction would help them build trust among participants and even prevent a possible misunderstanding of their role as interpreters. The introduction should explicitly mention that everything discussed in the session will remain strictly confidential. Interpreters should also refer to transparency and their impartial role during the session, since this would help prevent participants from asking interpreters for their opinion or seeking cooperation that is not impartial. Providing this information is essential to ensure smooth interaction between interpreters and participants, who might have never worked with interpreters before.

Again, coordinators could play a key role in raising awareness of the role of interpreters. First, while monitoring interpreters, coordinators could encourage them to always start their sessions with a brief introduction of their role. Coordinators could even provide a standard introduction for all the interpreters on their register to ensure that the basics are always conveyed. Second, coordinators often have direct contact with public service providers who hire PSI services, so before sessions take place coordinators could offer providers with information concerning the interpreter's role, functions and limitations.

\section{Conclusions}

The mixed approach adopted for the research presented in this article is a valuable method to collect data from a holistic perspective. The triangulation of the information obtained from these three groups of informants has been used as a validating method, but also as a way of describing the object of study in detail. The result is a description of certain aspects of PSI that take into account the points of view of different agents -namely, interpreters and mediators, coordinators and users. While interpreters and mediators present their experiences and perceptions of their own practice and their information forms the core of the data, coordinators' and users' views are used to contrast and supplement the information from the first sample. Coordinators display a more prescriptive approach to PSI, while users share a more informal perspective, based only on their personal experiences.

The importance of training is stressed throughout the discussion. In Catalonia, the lack 
of PSI courses until $2011^{15}$ and the rapid development of PSI services resulted in the employment of bilinguals who had not received specific training in PSI -some of them had only taken some training in IM-, which may be one of the reasons why many of the informants in the first sample explicitly acknowledged their doubts about their own interpreting performance. The kind of research presented in this article, based on fieldwork and reflecting real practice, provides very valuable information to improve training, especially considering the shortcomings observed in the data collected.

Moreover, researchers should try to ensure their results reach real PSI practitioners and, in this regard, the critical role of PSI service providers has also been highlighted. If research aims to change and improve the object of study, this bridge between research and practice is necessary. It is therefore important that researchers adopt a more advisory role towards the agents directly involved in PSI - i.e. coordinators and interpreters.

Finally, studies like the one presented in this article that focus on a specific language pair may be useful to assess whether the theories described in general research are applicable to any language combination or whether, instead, exceptions should be considered. In the case of PSI for Chinese users, Chinese linguistic diversity and the viability of relying on interpreters with specific Chinese varieties should always be considered, taking into account local circumstances. Furthermore, studies focusing on specific language combinations should be especially taken into account when adopting a prescriptive approach to PSI and when, for instance, developing codes of professional conduct aimed at covering any combination of languages and cultures.

\section{References}

Abril, I.; Martin, A. (2008) Profesionalizar en la práctica: La competencia en interpretación en los servicios públicos como base para la formación de profesionales. In C. Valero Garcés (ed.), Investigación y Práctica en Traducción e Interpretación en los Servicios Públicos. Desafíos y Alianzas. Alcalá de Henares: Universidad de Alcalá, 103-120. Agència de Salut Pública de Barcelona (ed.) (2001). Immigració i serveis sanitaris a la ciutat de Barcelona. La perspectiva de la població marroquina, xinesa, equatoriana $i$ paquistanesa. Retrieved from http://www.aspb.es/quefem/docs/Immigracio.pdf

\footnotetext{
15 In 2011-12, the MIRAS research group provided the first course in Catalonia specialising in PSI. In 2012-13 the course became a postgraduate degree (see http://pagines.uab.cat/formacio_isp_catalunya/, accessed 30 $0^{\text {th }}$ May 2013). Previously, only short, ad hoc courses (40 hours) had been taught in Catalonia.
} 
Angelelli, C. (2001). Deconstructing the Invisible Interpreter: a Study of the Interpersonal Role of the Interpreter in a Cross-Linguistic/Cultural Communicative Event. PhD thesis. Stanford University.

Arumí, M.; Gil-Bardají, A.; Vargas-Urpi, M. (2011). Traducció i Immigració: La figura de l'intèrpret al serveis públics de Catalunya. Quaderns, 18, 199-218. Retrieved from http://www.raco.cat/index.php/QuadernsTraduccio/article/view/245286/328509

Bancroft, M; Rubio-Fitzpatrick, L. (2011). The Community Interpreter. Columbia: Crosscultural Communications.

Baraldi, Claudio (2009). Forms of mediation: the case of interpreter-mediated interactions in medical systems. Language and Intercultural Communication, 9 (2), 120-137. doi: $10.1080 / 14708470802588393$

Beltrán Antolín, J.; Sáiz López, A. (2001). Els xinesos a Catalunya. Família, eduació i integració. Barcelona: Fundació Jaume Bofill; Editorial Altafulla.

Beltrán Antolín, J. (2009). La inmigración china en Cataluña. In. J. Julià-Muné (ed.), Visions de la Xina: cultura mil·lenària. Lleida: Institut d’Estudis Ilerdencs, 125-150.

Bi，J. (毕继万) (1998). Kuawenhua Fei-yuyan Jiaoji [跨文化非语言交际]. Beijing: Waiyu Jiaoxue yu Yanjiu Chubanshe [外语教学与研究出版社].

Bischoff, A.; Loutan, L.; García-Beyaert, S. (2009). En otras palabras: Guía para la consulta médica intercultural. Universal Doctor Project. Retrieved from: http://www.universaldoctor.com/EnOtrasPalabras/En_otras_palabras.pdf

Dong, X. (2008). Chinese Requests in Academic Settings. In K.M. Chan and H. Kang (eds.), Proceedings of the 20th North American Conference on Chinese Linguistics, vol. II. Ohio: Ohio State University, 975-988.

Edwards, R.; Temple, B.; Alexander, C. (2005). Users’ experiences of interpreters. The critical role of trust. Interpreting, 7, 77-96. doi: 10.1075/intp.7.1.05edw

Gadamer, H. G. (1975). Truth and Method. New York: Seabury Press.

Gadamer, H. G., (1977). Philosophical Hermeneutics. Berkeley, CA: University of California Press.

Gao, G. (1998). “Don’t take my word for it.” - Understanding Chinese speaking practices. International Journal of Intercultural Relations, 22 (2), 163-186. doi: 10.1016/S01471767(98)00003-0

Gao, G.; Ting-Toomey, S. (1998). Communicating effectively with the Chinese. Thousand Oaks, CA: Sage. 
Giménez Romero, C. (1997). La naturaleza de la mediación intercultural. Migraciones, 2, 125-159.

Goffman, E. (1967). Interaction ritual: essays in face-to-face behavior. New York: Pantheon Books, Random House.

Hamed, Abdula (2009). The problems of China's Health care system. Hamburg: Bachelorarbeit.

Hertog, E., Van Gucht, J.; de Bontridder, L. (2006). Musings on Methodology. Linguistica Antverpiensia, 5, 121-132. Retrieved from: https://lans.ua.ac.be/index.php/LANSTTS/article/view/156/93

Ho Wong, T. (2009). La salut en els pacients xinesos. In: Mediació intercultural en l'àmbit de la salut. Programa de formació. Barcelona: Fundació La Caixa, chapter 24. Retrieved from:

http://obrasocial.lacaixa.es/deployedfiles/obrasocial/Estaticos/pdf/Inmigracion/Mediacio _intercultural_es.pdf

Holroyd, E.; Twinn, S.; Yim, I. (2005). Exploring Chinese Women’s Cultural Beliefs and Behaviours Regarding the Practice of "Doing the Month”. Women and Health, 40, 109123. doi: 10.1300/J013v40n03_08

Hu, H. (1944). The Chinese concepts of “face”. American Anthropologist, 46, 45-64. doi: 10.1525/aa.1944.46.1.02a00040

Hwang, K. (1987). Face and Favor: The Chinese Power Game. The American Journal of Sociology, 92, 944-974. doi: 10.1086/228588

Katan, D. (1999). Translating cultures. Manchester: St. Jerome.

Kaufert, J.; Putsch, R. W. (1997) Communication through interpreters in healthcare: ethical dilemmas arising from differences in class, culture, language, and power. Journal of Clinical Ethics 8 (1), 71-87.

Linguamón (coord.) (2010). Els serveis de traducció, interpretació i mediació en els processos d'acolliment lingüístic a Catalunya. Barcelona: Linguamón. Retrieved from: http://www10.gencat.cat/casa_llengues/binaris/informe_linguamon_serveis_interpretaci o_immigracio_tcm302-116935.pdf

Martin, J. (1998). Chinese culture and social work. Australian Social Work, 51 (2), 3-8. doi: $10.1080 / 03124079808411212$

Mayring, P. (2000). Qualitative Content Analysis. Forum Qualitative Sozialforschung/Forum: Qualitative Social Research, 1 (2), art. 20. Retrieved from: http://www.qualitativeresearch.net/index.php/fqs/article/view/1089/2386 
Pöchhacker, F. (2008). Interpreting as mediation. In C. Valero Garcés and A. Martin (eds.), Crossing Borders in Community Interpreting: Definitions and Dilemmas. Amsterdam; Philadelphia: John Benjamins, 9-26.

Prats San Román, G.; Uribe Pinillos, E. (2009). La mediación intercultural. In Mediación intercultural en el ámbito de la salud. Programa de formación. Barcelona: Fundació La Caixa, chapter $15 . \quad$ Retrieved from http://obrasocial.lacaixa.es/deployedfiles/obrasocial/Estaticos/pdf/Inmigracion/Mediacio _intercultural_es.pdf

Qureshi, A. (2009). Comunicación intercultural y relación terapéutica. In Mediación intercultural en el ámbito de la salud. Programa de formación. Barcelona: Fundació La Caixa, chapter 13. Retrieved from http://obrasocial.lacaixa.es/deployedfiles/obrasocial/Estaticos/pdf/Inmigracion/Mediacio _intercultural_es.pdf

Qu, J.; Wang, L. (2005). Pragmatic Transfer in Compliment Responses by Chinese Learners of English. Sino-English Teaching, 2 (12), 66-75.

Raga, F. (2009). Atención sanitaria a la población origen chino. In Salud y Cultura. Portal informativo para la mediación intercultural y la interpretación en el ámbito sanitario. Grupo CRIT. Universitat Jaume I. Retrieved from http://www.saludycultura.uji.es/china.php

Rovira-Esteva, S. (2010). Lengua y escritura chinas. Mitos y realidades. Barcelona: Edicions Bellaterra.

Rudvin, M. (2007). Professionalism and ethics in community interpreting: The impact of individualist versus collective group identity. Interpreting, 9, 47-69. doi: 10.1075/intp.9.1.04rud

Rudvin, M.; Tomassini, E. (2008). Migration , ideology and the interpreter-mediator. The role of the language mediator in educational and medical settings in Italy. In C. Valero Garcés; A. Martín (eds.), Crossing Borders in Community Interpreting. Definitions and dilemmas. Amsterdam; Philadelphia: John Benjamins, 245-266.

Sales Salvador, D. (2003). Interacción comunicativa intercultural con inmigrantes procedentes de la cultura china. In CRIT group (ed.), Claves para la comunicación intercultural. Castelló de la Plana: Universitat Jaume I, 123-148.

Sánchez Pérez, M. (2009). La mediación intercultural en el ámbito sanitario. El caso de los pacientes de origen chino. MA Thesis. Universitat Jaume I. Retrieved from http://www.saludycultura.uji.es/archivos/La_mediacion_intercultural_en_el_ambito_san 
$\underline{\text { itario_El_caso_de_los_pacientes_de_origen_chino.pdf }}$

Sproston, K.; Pitson, L. B.; Walker, E. (2001). The Use of Primary Care Services by the Chinese Population Living in England: Examining Inequalities. Ethnicity and Health, 6, 189-196. doi: 10.1080/13557850120078116

Sun, J. K. (2010). Deciphering the Chinese Smile: The Importance of Facial Expressions in Linguistic Communication. Cross-sections VI, 105-120.

Valero Garcés, C.; Lázaro Gutiérrez, R. (2008). Investigación sobre la calidad de la comunicación en la atención sanitaria a la población inmigrante. In C. Valero Garcés (ed.). Investigación y Práctica en Traducción e Interpretación en los Servicios Públicos. Desafíos y Alianzas. Alcalá de Henares: Universidad de Alcalá.

Vargas-Urpi, M. (2012). La interpretació als serveis públics i la mediació intercultural amb el col-lectiu xinès a Catalunya. Thesis. Universitat Autònoma de Barcelona. URL: http://www.tdx.cat/handle/10803/96486 (accessed 31st May 2013).

Vargas-Urpi, M. (2013). Interpretación en los servicios públicos y/o mediación intercultural: la realidad de los profesionales que trabajan en el contexto catalán. Cuadernos de ALDEEU, 25, 131-164.

Vargas-Urpi, M.; Gil-Bardají, A.; Arumí, M. (2013). Inmigrantes en Cataluña: ¿Una comunicación efectiva en los servicios públicos? Hermeneus 15, 291-332.

Yang, J. (2008). How to say 'No' in Chinese: A Pragmatic Study of Refusal Strategies in Five TV Series. In M. Chan; H. Kang (eds.), Proceedings of the $20^{\text {th }}$ North American Conference on Chinese Linguistics (NACCL-20), vol. 2. Ohio: Ohio State University, 1041-1058.

Ytreland K. (2004). The role of the interpreter in international negotiations. MA thesis. Norwegian School of Economics and Business Administration, University of Bergen.

Yu, M. (2003). On the universality of face: evidence from Chinese compliment response behavior. Journal of Pragmatics, 35, 1679-1710. doi: http://dx.doi.org/10.1016/S03782166(03)00074-2 


\section{Appendix 1: Questionnaire used for data collection from Chinese immigrants}

华人用户对加泰罗尼亚地区卫生及公共服务部门使用情况及意见调查表

本次调查是一份整体情况分析报告的一个组成部分。全部的研究将采集相关各方面人员 （包括用户，译员，文化协调员，服务单位）各自的意见。

首先感谢您的积极参与, 同时我们保证对您所提供的信息严格保密。

在填写过程中, 如有需要, 您可以对一个问题做出多项选择。

1. 您去卫生及公共服务部门办事时, 有没有沟通问题?
口有
口没有
$\square$ 偶尔有

哪些部门?

$\square$ 医院和医疗中心

警察局和法院

$\square$ 社会福利部门

口学校

口便民服务办公室

$\square$ 其它, 请指明具体部门

2. 您在卫生及公共服务部门会使用哪一种方式来沟通?
口用简单的西班牙语
口用简单的加泰兰语
$\square$ 其它语言, 请指明具体语种:
口用手势
口用画图或纸条
口使用电子双语翻译工具
口借助翻译和文化协调员的帮助
$\square$ 请会说西班牙语或加泰兰语的亲戚, 朋友帮忙
口 借助电话口译服务

3. 您在卫生及公共服务部门办事时, 更喜欢使用哪种沟通方式?

$\square$ 虽然我的西班牙语水平非常有限, 但是还是喜欢自己办理。

口 请会说西班牙语或加泰兰语的亲戚, 朋友帮忙。

口借助专业翻译和文化协调员的帮助。

4. 如有其他人陪您一起去卫生及公共服务部门办事, 他一般会是:
口自己的子女。请写出他/她的年龄:
口配偶
其他亲戚
口会说西班牙语或加泰兰语的中国朋友
$\square$ 会说中文的西班牙朋友
口 卫生及公共服务部门的专业翻译与文化协调员
口自费的专业翻译

5. 您最喜欢谁的帮助?
$\square$ 自己的子女
配偶
其他亲戚
$\square$ 会说西班牙语或加泰兰语的本国朋友
$\square$ 会说中文的西班牙朋友
口 卫生及公共服务部门的专业翻译与文化协调员
口自费的专业翻译 
6. 您对这些人的帮助或服务满意吗?
亲戚
$\square$ 是 $\square$ 否
朋友
$\square$ 是 $\square$ 否
专业的翻译与文化协调员
$\square$ 是 $\square$ 否
自费的专业翻译
$\square$ 是 $\square$ 否

为什么?

7. 如果有专业翻译或者文化协调员陪您一起去卫生及公共服务部门办事, 您会不会在事前或 者事后跟他谈论您需要办理的事情?
口 会
不会
偶尔会

8. 您认为您的陪同翻译是否完整地翻译了服务机构工作人员所说的话?

$\begin{array}{ll}\text { 亲戚 } & \square \text { 是 } \square \text { 否 } \\ \text { 朋友 } & \square \text { 是 } \square \text { 否 } \\ \text { 专业的翻译与文化协调员 } & \square \text { 是 } \square \text { 否 } \\ \text { 自费的专业翻译 } & \square \text { 是 } \square \text { 否 }\end{array}$

9. 您认为您的陪同翻译是否完整地翻译了您对服务机构工作人员所说的话?
亲戚
$\square$ 是 $\square$ 否
朋友
$\square$ 是 $\square$ 否
专业的翻译与文化协调员
$\square$ 是 $\square$ 否
自费的专业翻译
$\square$ 是 $\square$ 否

10. 当您求助于专业翻译或文化协调员时, 她/他除了翻译工作之外是否也帮您处理别的相关 事务?

$\square$ 是 $\square$ 否

哪些别的事务?
口 替您填表
口替您打电话
口陪同您去某处
$\square$ 其它, 例如

11. 您是否曾经因为翻译或文化协调员的翻译失误而蒙受损害?

$\square$ 是 $\square$ 否

如果您选择了 “是”, 请指明是在下面哪类部门发生的:
口医院和医疗中心
口 警察局和法院
$\square$ 社会福利部门
$\square$ 学校
口 便民服务办公室
口其它，请指明具体部门 . . . . . . . . . . . . . . 
您可否举个例子, 并说明对您造成的影响及后果。

12. 对您来说一位翻译或文化协调员应该具备哪些品质? 您最重视哪种品质?

13. 您比较喜欢下面哪种类型的专业翻译或文化协调员?

口当地会中文的专业翻译或文化协调员

口 会西语或加泰罗尼亚语的中国翻译或文化协调员

14. 您比较喜欢下面哪种类型的专业翻译或文化协调员?

\section{年龄}

性别

口2 5 岁以下

$\square$ 男性的

$\square 25$ 岁以上

口 女性

$\square$ 无所谓

$\square$ 无所谓

口 视情况而定。请指明具体情况

口 视情况而定。请指明具体情况

15. 当您听不懂您的翻译或文化协调员的翻译时，您会请她 / 他解释清楚吗?
$\square$ 会
$\square$ 不会

16. 当您求助于专业翻译或文化协调员, 他/她会向您解释加泰罗尼亚地区的风俗文化吗?
口会
口不会
$\square$ 偶尔会

17. 专业翻译或文化协调员在翻译过程中，态度是否会偏向一方？

$\square$ 是，帮助我方

$\square$ 是, 帮助服务机构的的工作人员

口 没有，他 / 她从来坚持中立

如果您选择了 “是”，可否举个例子?

18. 翻译或文化协调员会劝告您如何回答服务机构工作人员提出的问题吗?
口会
$\square$ 不会
口偶尔会

19. 您会问翻译或文化协调员应该怎样回答服务机构人员提出的问题吗?
$\square$ 会
$\square$ 不会
口偶尔会

20. 您是否遇到过听不懂您的语言或地方方言的翻译或文化协调员?

口 是

口否 
如果您选择了 “是” , 请问你们是怎么处理这个问题的?

21. 您有没有使用过电话口译服务?

口有白没有

如果您选择了 “有”, 请指明是在下面哪个部门

$\square$ 医院和医疗中心

口 警察局和法院

$\square$ 社会福利部门

$\square$ 学校

口便民服务办公室

口其它, 请指明具体部门

您对电话口译这种服务是否满意?

$\square$ 是

否

为什么?

22. 您觉得公共服务部门的翻译或文化协调服务有什么需要改进的地方? 
个人资料

性别:

男性

口 女性

年龄:

出生地点:

您已经在西班牙居住了.

年

子女人数:

目前居住城市：

职业:

子女们的年龄:

您的母语（如是方言, 请指明）

学历:

$\square$ 没上过学

$\square$ 小学

初中，高中

$\square$ 中高等专业技术学校。请注明专业

大学毕业。请注明专业

$\square$ 其它教育类型, 请具体指明

\section{研究者: (...) \\ 联系: (...)}

本次调查是我博士论文的一个组成部分。非常感谢您的合作！ 